\title{
Genetic variation and correlation of agronomic traits in meadow bromegrass (Bromus riparius Rehm) clones ${ }^{1}$
}

\author{
Variação genética e correlações entre caracteres agronômicos em clones de meadow \\ bromegrass (Bromus riparius ehm)
}

\section{Marcelo Renato Alves de Araújo ${ }^{2}$ Bruce Coulman ${ }^{3}$}

\begin{abstract}
Meadow bromegrass (Bromus riparius Rehm.) is a recently introduced pasture grass in western Canada. Its leafy production and rapid regrowth have made it a major grass species for pasturing beef animals in this region. As relatively little breeding work has been done on this species, there is little information on its breeding behaviour. The main objective of this study was to estimate total genetic variability, broad-sense heritability, phenotypic and genetic correlations. Forty-four meadow bromegrass clones were evaluated for agronomic characters. Genetic variation for dry matter yield, seed yield, fertility index, harvest index, plant height, plant spread, crude protein, neutral detergent fiber and acid detergent fiber, was significant. Broad-sense heritability estimates exceeded $50 \%$ for all characters. Heritability estimates were at least 3.5 times greater than their standard errors. Phenotypic and genetic correlation between all possible characters were measured. There was general agreement in both sign and magnitude between genetic and phenotypic correlations. Correlations between the different characters demonstrated that it is possible to simultaneously improve seed and forage yield. Based on the results, it appears that the development of higher yielding cultivars with higher crude protein, and lower acid and neutral detergent fibers concentration should be possible.
\end{abstract}

Key word: perennial grasses, heritability, phenotypic correlation, genotypic correlation.

\section{RESUMO}

Meadow bromegrass (Bromus riparius Rehm.) é uma gramínea forrageira para pastejo recentemente introduzida no oeste do Canadá. Sua produção de matéria verde aliada a uma rebrota rápida a transformou numa forrageira bastante utilizada no pastejo de gado de corte naquela região. Existe pouca informação sobre o comportamento da espécie quando submetida a trabalhos de melhoramento genético. O principal objetivo deste estudo foi, portanto, estimar a variabilidade genética total, a herdabilidade no sentido amplo, bem como as correlações fenotípicas e genotípicas. Caracteres agronômicos de quarenta e quatro clones de Meadow bromegrass foram avaliadas em dois locais. A variação genética, para produção matéria seca, produção de sementes, índice de fertilidade, índice de colheita, altura das plantas, diâmetro das plantas, proteina bruta, fibra em detergente ácido e fibra em detergente neutro, foi estatisticamente significativa. As estimativas de herdabilidade foram superiores a 50\%, para todos os caracteres avaliados. Estas estimativas superaram seu erro padrão em, no mínimo, 3,5 vezes. As correlações genotípicas e fenotípicas entres todos os caracteres também foram estimadas, sendo as mesmas similares tanto em sinal como em magnitudes. Estas correlações demostram que é possivel melhorar simultaneamente a produção de forragem e a de sementes. Estes resultados indicam que é possivel desenvolver cultivares com alta produtividade e altos teores de proteina bruta, associados a baixo teores de fibra.

Palavras-chave: gramíneas perenes, herdabilidade, correlação genética, correlação fenotípica.

\section{INTRODUCTION}

Meadow bromegrass (Bromus riparius Rehm. $2 n=10 x=70$ ), a reduced creeping type of bromegrass with good ability for regrowth, is native to southeastern Europe, the Caucasus, Turkey and Central Asia. Its use in North America began when the cultivar 'Regar', derived from a Turkish introduction, was registered in the United States in 1966, and in Canada in 1980. The cultivars 'Paddock' and 'Fleet' were released in 1987 by the Agriculture

\footnotetext{
${ }^{1}$ Parte da tese apresentada pelo primeiro autor à University of Saskatchewan em Saskatoon , Canadá para obtenção do título de Ph D (Bolsa concedida pela EMBRAPA).

${ }^{2}$ Embrapa Caprinos, Estrada Sobral-Groairas Km 4, 62011-970, Sobral-CE, Brazil. E-mail: araujom@cnpc.embrapa.br Corresponding author.

${ }^{3}$ Agriculture and Agri-Food Canada, Saskatoon Research Centre, 107 Science Place, Saskatoon, SK. S7N 0X2, Canada.
} 
and Agri-Food Canada Research Centre in Saskatoon, Sk. Canada (KNOWLES, 1990a, 1990b).

Knowledge of the relative magnitude of various genetic and environmental parameters for characters of economic importance is important before more efficient breeding procedures can be employed. Since economically important plant characters are largely, if not entirely, quantitatively inherited, they can be evaluated by using biometrical techniques. Biometrical evaluation permits the estimation of population genetic parameters such as means, genetic and environmental variances, heritabilities, genetic and phenotypic correlation coefficients, and expected genetic advances from selection.

In perennial forage grasses, additive gene action has been the main determinant of variation for many agronomic traits (BARKER \& KALTON, 1989; BURTON, 1989; MEYER \& FUNK, 1989). The heritabilities of various agronomic traits have been estimated in many forage grass species (see ARAUJO, 2001, for a comprehensive list). For smooth bromegrass, the magnitude of these estimates has varied among the traits measured, with lower estimates for characteristics under complex genetic control like forage yield (TAN et al., 1978; CASLER, 1998) and acid-detergent fiber (TAN et al., 1978) than for more simply inherited characters like plant height (ROSS et al., 1970).

Correlations between traits are of interest to determine whether selection for one trait will have an effect on another. In addition, selection could be practiced on a highly heritable trait which is correlated to a more complex trait such as yield. Correlations among traits have been estimated in many perennial forage grasses (ARAUJO, 2001).

In a recent study, ARAUJO \& COULMAN (2002), estimated phenotypic correlations among several characters measured in progenies of meadow bromegrass. They reported that forage yield was correlated with dry matter yield. Seed yield was positively correlated with fertility index, harvest index and plant height. Crude protein was negatively associated with neutral-detergent fibre and acid-detergent fibre. The two fibre measurements were positively correlated.

There is little information on breeding behaviour and methodology for meadow bromegrass. The purpose of this study was to estimate the total genetic variance, broad-sense heritability, phenotypic and genotypic correlation among different quantitative traits in clones of meadow bromegrass.

\section{MATERIALS AND METHODS}

\section{Experimental sites}

The experiments were conducted at the Agriculture and Agri-Food Canada Research Centres in Saskatoon and Melfort. The Saskatoon Research Centre is located at $52^{\circ} 07^{\prime} \mathrm{N}$, and $106^{\circ} 38^{\prime} \mathrm{W}$, in a semiarid continental climate (Kopppen modified classification). The soil type of the experimental area is characterized as Sutherland clay loam (Typic Haploboroll). N-P-K (100-50-0 kg per hectare) was applied to the trial. The Research Centre in Melfort is located at $52^{\circ} 52^{\prime} \mathrm{N}$, and $104^{\circ} 37^{\prime} \mathrm{W}$, with a semi-arid continental climate with silty clay loam (Black Chernozen) soil. As the area had been fallowed for the previous three years, no fertilizer was applied during the course of the experiment.

\section{Plant material}

During the winter of 1997, 44 clones were vegetatively propagated; single propagules were planted in root-trainers and placed in a growth cabinet for six weeks. Established propagules were moved to a cold frame on March 25, 1997.

The experiments containing the 44 clones were planted in Saskatoon on June 15, 1997 and in Melfort on June 5, 1997. At each location, propagules were space-planted $1 \mathrm{~m}$ apart in a randomized complete block design with six replicates. Each plot consisted of a single plant. A border row of Fleet meadow bromegrass plants (1 $\mathrm{m}$ apart) was planted at each side of the experiment.

\section{Characters measured}

The following characters were measured in 1998: Seed yield in $\mathrm{t} \mathrm{ha}^{-1}$; dry matter yield in $\mathrm{tha}^{-1}$ with sub-samples of $500 \mathrm{~g}$ dried at $60^{\circ} \mathrm{C}$; plant height in $\mathrm{cm}$; fertility index (ratio seed weight to panicle weight) in \%; plant spread in cm; harvest index in \%; and forage quality (acid-detergent fiber, neutraldetergent fiber and crude protein concentrations) at post-anthesis.

Forage quality parameters were determined by near-infrared reflectance spectroscopy (NIRS) using a Technicon InfraAlyzer 400 (fixed filter).

\section{Analysis of variance and heritability}

The analysis of variance for each character was performed according to the following model: $X_{\mathrm{ijk}}$ $=\mu+G_{i}+R_{j}\left(L_{k}\right)+L_{k}+(G L)_{i k}+E_{i j k}, i=1,2, \ldots . . n ; j=$ $1,2, \ldots, \mathrm{r} ; \mathrm{k}=1,2$, where $\mu$ is the general mean, and $\mathrm{G}$ and $\mathrm{L}$ designate effects of clones (genotypes) and locations, $\mathrm{R}(\mathrm{L})$ designates the replication effect within 
location, GL designates the effect of interactions, while $\mathrm{E}$ is the experimental error. All of these effects are random variables with expectation 0 and variances equal to $\sigma_{\mathrm{G}}^{2}, \sigma_{\mathrm{R}(\mathrm{L})}^{2}, \sigma_{\mathrm{L}}^{2}, \sigma_{\mathrm{GL}}^{2}$, and $\sigma_{\mathrm{E}}^{2}$, respectively.

Broad-sense heritabilities $\left(\mathrm{h}_{\mathrm{b}}{ }^{2}\right)$ were estimated on a phenotypic mean basis averaged over replications and locations as follows:

$$
h^{2}=\frac{\sigma^{2}{ }_{G}}{\sigma_{P H}^{2}}=\frac{\sigma_{G}^{2}}{\sigma_{G}^{2}+\frac{\sigma^{2}{ }_{G L}}{l}+\frac{\sigma_{E}^{2}}{r l}},
$$

where $\sigma^{2}{ }_{\mathrm{PH}}, \mathrm{r}$ and 1 are phenotypic variance, number of replications and locations, respectively, and $r=6$, $1=2$.

Phenotypic variance and heritability standard errors were estimated according to WRICKE \& WEBER (1986).

Phenotypic and genetic correlations, were obtained as described by FALCONER \& MACKAY (1996). The phenotypic correlation was tested using tables in STEEL \& TORRIE (1980). To date, no suitable test for the significance of genetic correlation is available.

\section{RESULTS AND DISCUSSION}

\section{Variances and heritabilities}

Estimation of variance components for the variables were calculated by equating the mean square to the expected means squares and solving. Each character differed greatly in the actual magnitude of its estimated variance components (Table 1). The interaction variances $\left(\sigma_{\mathrm{GL}}^{2}\right)$ were always smaller than the genetic variances $\left(\sigma_{\mathrm{G}}^{2}\right)$.

Differences among clones $\left(\sigma_{\mathrm{G}}^{2}\right)$ were highly significant $(\mathrm{P}<0.01)$ for all characters (Table 1$)$. The clone $\mathrm{x}$ location interaction $\left(\sigma_{\mathrm{GL}}^{2}\right)$ was also significant $(\mathrm{P}<0.01)$ for dry matter yield, seed yield, and spread. For fertility index and height the interaction was significant at $\mathrm{P}<0.05$ level. No significant interactions were found for harvest index, crude protein, neutral and acid detergent fibers.

Broad-sense heritability $\left(\mathrm{h}^{2}{ }_{\mathrm{b}}\right)$ estimates exceeded $50 \%$ for all characters. Heritabilities estimates were at least 3.5 times greater than their standard errors.

Literature on seed yield heritability of perennial forage grasses is limited and often outdated. Broad-sense heritability for seed yield $(72 \%)$ was superior to the estimates of $45 \%$ obtained by ANDRÉS \& GUILLEN (2001), but lower than the estimated value reported by SCHAAF (1976) of $83 \%$. The estimate in this latter study was not completely free of genotype-environmental bias due to the fact that just one year and one location were used.

It has often been stated that if selection pressure is exerted for seed yield, it could be achieved only at the expense of forage yield. Therefore it is useful to find correlated traits to permit the selection of forage cultivars with high forage and seed yields. WILKINS (1991) stated that seed set (fertility index) is of foremost importance in seed yield, because improvement for this trait would not affect forage production and it would have a correlated response in seed yield itself. BUGGE (1987) pointed out that fertility index would be a trait to pursue in breeding for high seed yield in forage perennial grasses. In the present study, broad-sense heritabilities for fertility index $(53 \%)$ were similar to estimates by BEAN (1972) and ELGERSMA (1990) in tall fescue and perennial ryegrass, respectively, but lower than those (61 and 82\%) reported by NGUYEN \& SLEPER

Table 1 - Estimates of variance components $\mathrm{s}^{\mathrm{z}}$, broad-sense heritability $\left(\mathrm{h}^{2}{ }_{\mathrm{b}}\right)$ and associated standard errors for nine traits in meadow bromegrass clones.

\begin{tabular}{|c|c|c|c|c|c|}
\hline Traits & $\sigma_{\mathrm{G}}^{2}$ & $\sigma_{\mathrm{GL}}^{2}$ & $\sigma_{E}^{2}$ & $\sigma_{\mathrm{PH}}^{2}$ & $\mathrm{~h}_{\mathrm{b}}^{2}(\%)$ \\
\hline Dry matter yield $\left(\mathrm{t} \mathrm{ha}^{-1}\right)$ & $0.0723 * *$ & $0.0480 * *$ & 0.3792 & 0.1279 & $57 \pm 14$ \\
\hline Seed yield $\left(\mathrm{t} \mathrm{ha}^{-1}\right)$ & $0.0098 * *$ & $0.0034 * *$ & 0.0257 & 0.0136 & $72 \pm 09$ \\
\hline Fertility index (\%) & $5.8296^{* *}$ & $4.0445^{*}$ & 37.3393 & 10.9635 & $53 \pm 15$ \\
\hline Harvest index (\%) & $6.0289 * *$ & 1.4272 & 19.8453 & 8.3963 & $72 \pm 09$ \\
\hline Height $(\mathrm{cm})$ & $48.1082 * *$ & $4.0600^{*}$ & 41.5903 & 53.6040 & $90 \pm 03$ \\
\hline Spread $(\mathrm{cm})$ & $3.1533 * *$ & $2.2146 * *$ & 14.6545 & 5.4819 & $58 \pm 13$ \\
\hline Crude protein $(\%)$ & $0.1317 * *$ & 0.0000 & 0.8585 & 0.2032 & $65 \pm 10$ \\
\hline Neutral detergent fiber $(\%)$ & $0.8074 * *$ & 0.6045 & 8.0222 & 1.5062 & $54 \pm 14$ \\
\hline Acid detergent fiber $(\%)$ & $0.4753 * *$ & 0.1298 & 2.5808 & 0.7553 & $63 \pm 12$ \\
\hline
\end{tabular}

****Mean square associated with variance component was significant at the 0.05 and 0.01 probability levels, respectively.

${ }^{\mathrm{z}} \sigma_{\mathrm{G}}^{2}=$ genetic variance, $\sigma_{\mathrm{GL}}^{2}=$ genotype $\mathrm{x}$ location variance, $\sigma_{\mathrm{E}}^{2}=$ error variance, and $\sigma_{\mathrm{PH}}^{2}=$ phenotypic variance. 
(1983) and BUGGE (1987) in tall fescue and ryegrass respectively.

The estimates of broad-sense heritability for dry matter yield (57\%) and for plant spread (58\%) in the present study were generally lower than those reported in the literature (ARAUJO, 2001). However, ARAUJO et al. (1983) pointed out that spreading ability is a trait mainly expressed in space-planted nurseries; thus, its usefulness in sward conditions is questionable.

For height, the majority of heritability estimates has been moderate to high (ARAUJO, 2001) indicating that a large portion of the genetic variance for this trait is additive. The generally high broad-sense heritabilities found for plant height in the present study confirms that this trait is mainly under additive genetic control in meadow bromegrass.

Estimates of broad-sense heritability for the quality parameters (crude protein, neutral detergent fiber, and acid detergent fiber) were above 50\%, similar to estimates reported by ARAUJO (2001).

The most convenient way to assess the heritability of a given trait is to use clonal material, which is easily obtained in grasses by splitting a plant into ramets of one or more tillers. In this manner, traits can be assessed in different locations. Based on clonal material, variances can be estimated and used to calculate $\mathrm{h}_{\mathrm{b}}{ }_{\mathrm{b}}$ (WRICKE \& WEBER, 1986; NYQUIST, 1991). When clonal propagation is practiced, $\mathrm{h}_{\mathrm{b}}{ }_{\mathrm{b}}$ indicates the response to clonal selection. Meadow bromegrass being a polyploid crop $(2 \mathrm{n}=10 \mathrm{x}=70)$ is also generatively propagated, therefore dominance and possibly some epistatic variances may exist in appreciable amounts. Thus $\mathrm{h}_{\mathrm{b}}{ }_{\mathrm{b}}$, estimated in this study, overestimates the response to selection. However according to NYQUIST (1991) it is not required that heritability estimates be unbiased, for in preliminary studies a biased estimates may be adequate to assess roughly the relative magnitude of the hereditary variation. Moreover many studies reported in the literature (BARKER \& KALTON, 1989; BURTON, 1989; MEYER \& FUNK, 1989; ARAUJO, 2001) have indicated that genetic variation for important traits in perennial forage grasses are under genetic additive control.

Based on the findings of this study clonal evaluation appeared to be adequate to select parents for more highly heritable characters such as seed yield, harvest index and height. It seems that a well designed clonal evaluation test, established in different locations over a 2 year period will yield sufficient information on genotype $\mathrm{x}$ environment interaction, freeing estimates of heritability from this kind of bias. The main factor in determining the total number of locations will, of course, be limitations of space and funding.

\section{Correlations}

Phenotypic $\left(r_{p}\right)$ and genetic $\left(r_{g}\right)$ correlation between all possible characters are presented in table 2. Since $\sigma^{2}{ }_{\mathrm{G}}$ and $\operatorname{Cov}_{\mathrm{G}}$ include not only additive effects, but also other genetic effects, estimates of genetic correlation should be considered as total genetic correlation. Thus, interpretation of these estimates should be made with caution. There was general agreement in both sign and magnitude between genetic and phenotypic correlations. Out of 36 genetic correlations only four were different in sign from their corresponding phenotypic correlations. These four particular phenotypic correlations were not different from zero. This suggests that, for the most part, the

Table 2 - Phenotypic (above diagonal) and genetic (below diagonal) correlation coefficients among nine traits in meadow bromegrass clones tested in 1998 at two locations.

\begin{tabular}{|c|c|c|c|c|c|c|c|c|c|}
\hline Traits & $\begin{array}{l}\text { Dry matter } \\
\text { yield }\end{array}$ & $\begin{array}{l}\text { Seed } \\
\text { yield }\end{array}$ & $\begin{array}{l}\text { Fertilit } \\
\text { y index }\end{array}$ & $\begin{array}{l}\text { Harves } \\
t \text { index }\end{array}$ & Height & Spread & $\begin{array}{l}\text { Crude } \\
\text { protein }\end{array}$ & $\begin{array}{c}\text { Neutral } \\
\text { detergent fiber }\end{array}$ & $\begin{array}{l}\text { Acid detergent } \\
\text { fiber }\end{array}$ \\
\hline Dry matter yield & & 0.27 & -0.22 & -0.26 & 0.19 & 0.23 & 0.02 & -0.05 & 0.04 \\
\hline Seed yield & 0.17 & & $0.60 * *$ & $0.84 * *$ & 0.18 & 0.24 & 0.13 & 0.02 & 0.07 \\
\hline Fertility index & -0.62 & 0.64 & & $0.71 * *$ & 0.19 & -0.05 & 0.01 & -0.07 & 0.04 \\
\hline Harvest index & -0.29 & 0.89 & 0.87 & & -0.00 & 0.12 & 0.11 & 0.04 & 0.09 \\
\hline Height & 0.16 & 0.10 & 0.14 & -0.04 & & -0.09 & -0.20 & 0.14 & $0.31 *$ \\
\hline Spread & 0.17 & 0.13 & -0.22 & 0.03 & -0.20 & & $-0.31^{*}$ & 0.30 & 0.29 \\
\hline Crude protein & 0.01 & 0.24 & 0.04 & 0.25 & -0.24 & -0.46 & & $-0.70 * *$ & $-0.52 * *$ \\
\hline Neutral detergent fiber & -0.14 & -0.05 & -0.22 & 0.01 & 0.15 & 0.52 & -0.72 & & $0.42 * *$ \\
\hline Acid detergent fiber & -0.10 & -0.04 & -0.03 & 0.03 & 0.37 & 0.35 & -0.62 & 0.46 & \\
\hline
\end{tabular}

****Significant at the 0.05 and 0.01 probability levels, respectively 
character correlation is similar for genetic and phenotypic effects.

Results from the literature (TAN et al., 1978; VOGEL et al., 1981; BERG \& HILL, 1983; VOGEL et al., 1993) indicate that the relationship between dry matter yield and crude protein are usually negative. Our findings showed coefficients not significantly different from 0 for these two characters. This suggests that meadow bromegrasss could be selected for high forage yield without reducing the crude protein concentration.

Correlations between dry matter yield and seed yield with height were not significant, similar to the finding obtained by ARAUJO \& COULMAN (2002). This suggests that selection would be effective to simultaneously improve both characters. In fact KNOWLES (1990a; 1990b) developed meadow bromegrass cultivars with both high forage and seed yield characteristics.

Correlations between seed yield and fertility index were positive and significant. These results agree with those reported elsewhere in the literature (GRIFFITH et al., 1978; BUGGE 1987; ARAUJO \& COULMAN, 2002). According to GRIFFITH et al. (1978) it is possible to improve fertility by breeding for seed production. According to the results here reported, it seems that it would be possible to select for higher seed yield by increasing the fertility index. In addition, no significant associations have been found in this study between dry matter yield and fertility index, thus selecting for fertility index would have no effect on forage yield.

The desirability of selecting for morphological traits to improve forage quality has been previously discussed (BHAT \& CHRISTIE, 1975; SLEPER \& DROLSOM, 1974; TAN et al., 1978). Our findings indicate that height, in most of the instances, shows no significant correlation with the quality parameter traits (crude protein, acid detergent fiber, and neutral detergent fiber), the exception being height and acid detergent fiber $\left(r_{p}=0.31, P<0.05\right)$.

Correlations between acid detergent fiber and neutral detergent fiber were significant and positive and were similar to those findings reported in the literature (STRATTON et al., 1979; SOH et al.,1984; ARAUJO, 2002). This is expected because the components of acid detergent fiber (mainly lignin and cellulose) are also components of neutral detergent fiber. On the other hand, correlations of crude protein with acid detergent fiber and neutral detergent fiber were significant and negative, similar results have been found by STRATTON et al. (1979), SOH et al. (1984) and ARAUJO \& COULMAN
(2002). Thus, selection for increased crude protein would result in lower fiber concentration, which would be desirable from the standpoint of forage quality. Based on the results of the present study the development of higher yielding cultivars with higher crude protein, and lower acid and neutral detergent fibers concentration should be possible.

\section{REFERENCES}

ANDRÉS, A.; GUILLEN. Genetic variability within two adapted populations of tall wheatgrass (Thynopyrum ponticum) in Argentina. In: INTERNATIONAL GRASSLAND CONGRESS, 19., 2001, Piracicaba. Proceedings... Piracicaba : FEALQ, 2001. p.485-486

ARAUJO, M.R.A.de; COULMAN, B.E. Genetic variation, heritability and progeny testing in meadow bromegrass. Plant Breeding, v.121 417-424, 2002.

ARAUJO, M.R.A. de. Variation and heritability in meadow bromegrass (Bromus riparius $\mathrm{Rehm}$.). 2001. 157f. PhD. Thesis (Melhoramento Genético de Plantas Forrageiras) - College of Graduate Studies and Research. University of Saskatchewan. Saskatoon, Canadá.

ARAUJO, M.R.A. et al. Genetic variation and correlation of agronomic traits in tall fescue (Festuca arundinacea Schreb.). Canadian Journal of Plant Science, v.63, p.453-460, 1983.

BARKER, R.E.; KALTON, K.K. Cool season forage grass breeding: progress, potentials, and benefits. In: SLEPER, D.A.; ASSAY, K.H.; PEDERSEN, J.F. Contribution from breeding forage and turf grasses. Madison : Crop Science Society of America, 1989. p.5-20. (CSSA Special Publication, 15).

BEAN, E.W. Clonal evaluation for increased seed production in two species of forage grasses, Festuca arundinacea Schreb. and Phleum pratense L. Euphytica, v.21, p.377-383, 1972.

BERG, C.C.; HILL, R.R. (Jr.). Quantitative inheritance and correlations among forage yield and quality components in timothy. Crop Science, v.23, p.380-384, 1983.

BHAT, A.N.; CHRISTIE B.R. Plant composition and in vitro digestibility in bromegrass genotypes. Crop Science, v.15, p.676679,1975

BUGGE, G. Selection for seed yield in Lolium perenne L. Plant Breeding, v.98, p.149-155, 1987.

BURTON, G. Progress and benefits to humanity from breeding warm-season forage grasses. In: SLEPER, D.A.; ASSAY, K.H.; PEDERSEN, J.F. Contribution from breeding forage and turf grasses. Madison : Crop Science Society of America, 1989. p.21-29. (CSSA Special Publication, 15).

CASLER, M.D. Genetic variation within eight populations of perennial forage grasses. Plant Breeding, v.117, p. 243-249, 1998.

ELGERSMA, A. Heritability estimates of spaced-plant traits in three perennial rye grass (Lolium perenne L.). Euphytica, v.51, p.163-171, 1990. 
FALCONER, D.S.; MACKAY, T.F.C. Introduction to quantitative genetics. 4.ed. Essex : Longman, 1996. 465p.

GRIFFITH D.J.; LEWIS; J.; BEAN, E.W. Problems of breeding for seed production in grasses. In: HEBBLETHWAITE, P.D (Ed). Seed production. London : Butterworths, 1978. p.37-49.

KNOWLES, R.P. Registration of 'Paddock' meadow bromegrass. Crop Science, v.30, p.741, 1990a.

KNOWLES, R.P. Registration of 'Fleet' meadow bromegrass. Crop Science, v.30, p.741, 1990b.

MEYER, W.A; FUNK, C.R. Progress and benefits to humanity from breeding cool-season grasses for turf. In: SLEPER, D.A.; ASSAY, K.H.; PEDERSEN, J.F. Contribution from breeding forage and turf grasses. Madison : Crop Science Society of America, 1989. p.31-48. (CSSA Special Publication, 15).

NGUYEN, H.T.; SLEPER, D.A. Genetic variability of seed yield and reproductive characters in tall fescue. Crop Science, v.23, p.621-626, 1983.

NYQUIST, W.E. Estimation of heritability and prediction of selection response in plant populations. Critical Reviews in Plant Sciences, v. 10, p. 235-322., 1991.

ROSS, J.G.; BULLIS, S.S.; LIN, K.C. Inheritance of in vitro digestibility in smooth bromegrass. Crop Science, v.10, p.627633, 1970.

SCHAAF, H.M. Spaced-planted and mass-seeded progeny tests for seed yield and seed size in tetraploid crested wheatgrass. Crop Science, v.16, p.607-610, 1976.

SOH, A.C. et al. Genetic variation in acid detergent fiber, neutral detergent fiber, hemicellulose, crude protein, and their relationship with in vitro dry matter digestibility in tall fescue. Crop Science, v.24, p.721-727, 1984.

SLEPER, D.A.; DROLSOM, P.N. Analysis of several morphological traits and their associations with digestibility in Bromus inermis Leyss. Crop Science, v.14, p.34-36, 1974

STEEL, R.G.D.; TORRIE, J.G. Principles and procedures of statistics. 2.ed. New York : McGraw-Hill, 1980. 633p.

STRATTON, S.D.; SLEPER, D.A.; MATCHES, A.G. Genetic variation and interrelationships of in vitro dry matter disappearance and fiber content in orchardgrass herbage. Crop Science, v.19, p.329-333, 1979.

TAN, W.K.; TAN, G.Y.; WALTON, P.D. Genetic variability in acid detergent fiber, crude protein, and their association with some morphological characters in smooth bromegrass. Crop Science, v.18, p. 119-121, 1978.

VOGEL, K.P.; GORZ, H.J.; HASKINS, F.A. Heritability estimates for forage yield, in vitro dry matter digestibility, crude protein, and heading date in indiangrass. Crop Science, v.21, p.35-38, 1981.

VOGEL, K.P.; REECE, P.E.; NICHOLS, J.T. Genotype and genotype $\mathrm{x}$ environment interaction effects on forage yield and quality of intermediate wheatgrass in swards. Crop Science, v.33, p.37-41, 1993.

WILKINS, P.W. Breeding perennial ryegrass for agriculture. Euphytica, v.52, p.201-214, 1991.

WRICKE, G.; WEBER, W.E. Quantitative genetics and selection in plant breeding. New York: Walter de Gruyter, 1986. 406p. 